\title{
PENGARUH MODEL PEMBELAJARAN CONCEPT SENTENCE TERHADAP KETERAMPILAN MENULIS CERPEN PADA SISWA KELAS XI MIA SMA MUHAMMADIYAH 18 SUNGGAL TAHUN PELAJARAN 2019/2020
}

\author{
Fitria Dinda Sri Wardani ${ }^{1}$, Prina Yelly ${ }^{2}$, Sri Wahyuni ${ }^{3}$ \\ fitriadindasriwardani@gmail.com,prinayelly4@gmail.com,yuni210984@gmail.com \\ STKIP BUDIDAYA BINJAI
}

\begin{abstract}
ABSTRAK
Penelitian ini bertujuan untuk mengetahui besarnya pengaruh model pembelajaran concept sentence terhadap keterampilan menulis cerpen Metode penelitian yang digunakan adalah penelitian eksperimen. Populasi dalam penelitian ini adalah seluruh siswa kelas XI MIA SMA Muhammadiyah 18 Sunggal yang terdiri dari 2 kelas, dan yang menjadi sampel pada penelitian ini yaitu berjumlah 59 siswa yang terdiri dari 2 kelas di mana kelas MIA 1 sebagai kelas eksperimen dan kelas MIA 2 sebagai kelas kontrol. Pengambilan sampel dilakukan dengan teknik Random Sampling. Data dalam penelitian ini menggunakan perhitungan statistik atau penggunaan tabel-tabel statistik dengan cara menghitung nilai rata-rata, standart deviasi, uji normalitas, uji homogenitas, dan uji hipotesis. Dari hasil uji t dapat disimpulkan terdapat pengaruh model pembelajaran concept sentence terhadap keterampilan menulis cerpen.
\end{abstract}

Kata Kunci: Concept Sentence, Keterampilan Menulis Cerpen. 


\section{PENDAHULUAN}

Standar kompetensi mata pelajaran bahasa Indonesia berorientasi pada hakikat pembelajaran bahasa dan sastra. Belajar bahasa adalah belajar berkomunikasi, sedangkan belajar sastra adalah belajar menghargai manusia dan nilai-nilai kemanusiaannya.

Sastra merupakan bagian dari mata pelajaran bahasa Indonesia yang memiliki fungsi sebagai penghalus budi, peningkatan kepekaan, rasa

kemanusiaan, kepedulian sosial, penumbuhan apresiasi budaya dan penyaluran gagasan, imajinasi dan ekspresi secara kreatif dan konstruktif, baik secara lisan maupun secara tertulis. Melalui sastra, siswa diajak untuk memahami, menikmati, dan menghayati karya sastra.

Pembelajaran bahasa Indonesia di sekolah tidak akan terlepas dari empat aspek keterampilan berbahasa, yaitu menyimak, berbicara, membaca, dan menulis. Keterampilan berbahasa bermanfaat untuk melakukan interaksi komunikasi dalam masyarakat.Dari keempat keterampilan berbahasa, menulis merupakan salah satu keterampilan berbahasa yang mempunyai peranan penting.

Menulis merupakan suatu keterampilan berbahasa yang dipergunakan untuk berkomunikasi secara tidak langsung, tidak secara tatap muka dengan orang lain. Menulis merupakan suatu kegiatan yang produktif dan ekspresif (Tarigan, 1994: 3-4).

Sesuai dengan kurikulum tahun 2013 (K13) kegiatan pembelajaran menulis cerpen biasa dilakukan di kelas. Siswa dituntut untuk membuat sebuah cerpen. Dunia pendidikan menulis mempunyai arti yang sangat penting. Siswa yang sering menulis akan terampil dan terarah kemampuan berekspresinya sehingga secara tidak langsung akan mempertajam kemampuan berpikir. Salah satu keterampilan yang harus dilakukan siswa di sekolah menengah atas (SMA) adalah menulis cerpen.

Cerpen lahir dan berkembang di Eropa Barat, Rusia, dan Amerika pada abad ke-19, bersama munculnya majalah-majalah umum. Pada tahun 1812, di Jerman muncul penulis Jacob Grimm dan Wilhelm Grimm yang banyak menerbitkan cerita pendek berdasarkan penyelidikannya terhadap cerita rakyat. Model pembelajaran Concept Sentence merupakan model pembelajaran yang dilakukan dengan cara memberikan kartu-kartu yang berisi beberapa kata kunci kepada siswa, kemudian kata kunci tersebut dikembangkan menjadi paragraf- paragraf.

\section{Model Concept Sentence}

menempatkan siswa dalam kelompok yang beranggotakan kurang lebih 4 siswa. Guru menyajikan beberapa kata kunci sesuai materi yang disajikan. Setiap kelompok diarahkan membuat beberapa kalimat/paragraf dengan menggunakan beberapa kata kunci yang diberikan.

Setelah dilakukan observasi awal 
berupa wawancara dengan guru mata pelajaran bahasa Indonesia, yaitu Ibu Deby Anggraini Pohan, S.Pd pada tanggal 18 Februari 2019 di SMA Muhammadiyah 18 Sunggal khususnya kelas XI, setelah observasi diperoleh informasi bahwasannya minat siswa dalam belajar masih rendah khususnya dalam menulis cerpen. Diperoleh juga informasi bahwa masih banyak siswa yang kurang mampu untuk memulai melakukan kegiatan menulis, siswa selalu beranggapan bahwa pembelajaran menulis merupakan suatu materi yang sulit, siswa juga merasa kesulitan mengembangkan ide dan gagasan- gagasan dalam cerpen.

Cerita pendek (cerpen) adalah cerita yang menurut wujud bisiknya berbentuk pendek. Ukuran panjang pendeknya suatu cerita memang relatif. Namun, pada umumnya cerita pendek merupakan cerita yang habis dibaca sekitar sepuluh menit atau setengah jam. Jumlah katanya sekitar 5005.000 kata. Karena itu, cerita pendek sering diungkapkan dengan cerita yang dapat dibaca dalam sekali duduk (Kosasih, 2003:222).

Cerita pendek sebagai genre fiksi) adalah rangkaian peristiwa yang terjalin menjadi satu yang di dalamnya terjadi konflik antartokoh atau dalam diri tokoh itu sendiri dalam latar dan alur (Kurniawan dan Sutardi, 2012:59).

Selain ciri-ciri dan syarat, cerpen juga mempunyai beberapa unsur, yaitu sebagai berikut; (1) Tema, (2) Alur, (3)
Latar, (4) Penokohan, (5) Sudut Pandang,

(6) Amanat, dan (7) Gaya bahasa (Aminuddin, 2007; 223-231).

\section{METODE}

Penelitian ini akan dilaksanakan di SMA Muhammadiyah 18 Sunggal yang berlokasi di Jalan Sei Mencirim Nomor 60, Medan Krio, Kecamatan Sunggal, Kabupaten Deli Serdang, Sumatera Utara 20351. Penelitian ini akan dilakukan di kelas XI Mia Tahun Pelajaran 2019/2020. Penelitian ini dilaksanakan pada semester ganjil tahun pelajaran 2019/2020.

populasi dalam penelitian ini adalah keseluruhan subjek yang akan diteliti yaitu siswa kelas XI MIA SMK Muhammadiyah 18 Sunggal Tahun Pelajaran 2019/2020 yang berjumlah 59 orang siswa, "sampel adalah bagian dari jumlah dan karakteristik yang dimiliki oleh populasi tersebut. Arikunto mengatakan bahwa "Untuk sekedar ancerancer, maka apabila subjeknya kurang dari 100, lebih baik diambil semua sehingga penelitiannya merupakan penelitian populasi. Selanjutnya jika jumlah subjeknya besar dapat diambil antara $10-15 \%$ atau 20$25 \%$ atau lebih. maka sampel yang diambil seluruhnya, yaitu berjumlah 59 siswa yang terdiri dari 2 kelas di mana kelas MIA 1 sebagai kelas eksperimen dan kelas MIA 2 sebagai kelas kontrol. Penentuan kelas eksperimen dan kelas kontrol menggunakan Random Sampling.

Penelitian eksperimen ini bertujuan 
untuk mencari tahu ada tidaknya pengaruh $\begin{array}{llll}\text { antara } & \text { variabel } & \mathrm{x} & \text { (model }\end{array}$ pembelajarancconcept sentence) terhadap variabel y (kemampuan menulis cerpen). Namun, dalam penelitian ini akan digunakan penelitian dengan desain Only Posttes Two Group.

Dalam penelitian ini menggunakan dua variabel, yaitu variabel bebas dan variabel terikat.

\section{a. Variabel Bebas}

Variabel bebas adalah variabel yang memengaruhi. Variabel bebas dalam penelitian ini adalah model pembelajaran concept sentence, dengan kode (X).

b. Variabel Terikat

Variabel terikat adalah vaiabel yang dipengaruhi atau yang diselidiki hubungannya. Dalam penelitian ini yang dijadikan variabel terikat adalah kemampuan siswa menulis cerpen, dengan kode $(\mathrm{Y})$.

c. Hubungan antara Variabel

Dalam penelitian ini variabelnya ganda. Maka variabel yang satu mempunyai hubungan dengan variabel yang lain.
Variabel X (variabel bebas) memengaruhi variabel Y (variabel terikat).

Instrumen dalam penelitian ini menggunakan tes hasil belajar. Tes yang digunakan adalah tes uraian di mana siswa disuruh membuat cerpen dengan tema kasih sayang. Adapun penelitian tes berdasarkan unsur intrinsik cerpen.

Teknik analisis data dalam penelitian ini dengan menggunakan metode deskriptif yaitu menganalisis data-data dalam upaya pemecahan masalah yang diteliti dengan menggambarkan objek penelitian berdasarkan fakta-fakta yang ditemukan pada waktu penelitian kelokasi penelitian sebagaimana adanya. Sedangkan dalam menganalisis data, yang bersifat kualitatif diolah dan dianalisis berdasarkan penguraian-penguraian, sistematis, faktual, sehingga dapat dibuktikan kebenarannya. Sedangkan, data yang bersifat kuantitatif diolah dan dianalisa dengan perhitungan statistik atau penggunaan tabel-tabel statistik, yaitu :

\section{a. Mencari Rata-rata Hitung}

$$
X=\frac{\sum x_{1}}{N}
$$

Keterangan :

$$
\begin{array}{ll}
\mathrm{X} & =\text { Mean (rata-rata) } \\
\Sigma X_{1} & =\text { Jumlah Nilai Tes } \\
\mathrm{N} & =\text { Jumlah Sampel }
\end{array}
$$

b. Mencari Standart Deviasi

$$
S^{2}=\sqrt{\frac{n \sum x_{\mathrm{i}}^{2}-(\sqrt{\Sigma \bar{x}}}{n(n-1)}}
$$


Keterangan :

$$
\begin{array}{ll}
\mathrm{S}^{2} & =\text { Standart Deviasi } \\
\Sigma X_{1}{ }^{2} & =\text { Rata-rata Nilai Tes } \\
\mathrm{N} & =\text { Jumlah Sampel }
\end{array}
$$

\section{c. Uji Normalitas}

Uji normalitas dengan

menggunakan uji liliefors,

langkah-langkah yang

dilakukan sebagai berikut:

a. Pengamatan $X_{1}, X_{2}, \ldots . . X_{n}$ dijadikan angka baku $\mathrm{Z}_{1}$,

$\mathrm{Z}_{2}, \quad \ldots \ldots . \quad \mathrm{Z}_{\mathrm{n}} \quad$ dengan menggunakan rumus:

$$
Z i=\frac{\mathrm{x}-\bar{x}}{\mathrm{~s}}
$$

Keterangan : 


$$
\begin{aligned}
& X=\text { Rata-rata skor } \\
& \mathrm{S}=\text { Simpangan baku sampel }
\end{aligned}
$$

b. Untuk tiap bilangan baku ini menggunakan daftar distribusi normal baku, kemudian dihitung peluang $\mathrm{F}\left(\mathrm{Z}_{1}\right)=\mathrm{P}\left(\mathrm{Z} \leq \mathrm{Z}_{1}\right)$. c. Selanjutnya hitung proporsi $Z_{1}, Z_{2}, \ldots$. $Z_{n}$ yang lebih kecil atau sama dengan $Z_{i}$ jika proporsi ini dinyatakan oleh $S$ (Zi) maka:

$$
S(Z \mathrm{i})=\frac{\text { Banyaknya } \mathrm{Z} 1, \mathrm{Z} 2, \ldots \mathrm{Zn} \text { yang } \leq \mathrm{Zi}}{n}
$$

d. Hitungan selisih $F\left(Z_{i}\right)-S\left(Z_{i}\right)$ kemudian menentukkan harga mutlaknya.

daftar, untuk taraf nyata $\alpha=0,05$ dengan kriteria :

e. Ambillah harga mutlak terbesar

a. Jika Lo < L tabel maka data berdistribusi normal. disebut (Lo) untuk menerima atau menolak hipotesis, kita bandingkan

b. Jika Lo > L tabel maka data tidak berdistribusi normal.

Lo dengan kritis L yang diambil dari

d.

\section{Uji Homogenitas}

Pengujian homogenitas adalah mengenai sama tidaknya variasivariasi dua buah distribusi atau lebih. Untuk menguji apakah varians kedua sampel homogen digunakan uji homogenitas dengan hipotesis: $\mathrm{H}_{0}: \sigma^{2}=\sigma^{2}$ (data berasal dari populasi yang varians sama)

$\mathrm{H}_{1}: \sigma^{2} \neq \sigma^{2}$ (data berasal dari populasi ${ }_{1}$ yang varians berbeda)

Pengujian dilakukan dengan menggunakan uji kesamaan variansi (uji F) 


\section{$F \frac{\text { Varianster besar }}{\text { Varianster kecil }}$}

Jika $F_{\text {hitung }}<\mathrm{F}_{\text {tabel }}$ maka Ho diterima, Jika $F_{\text {hitung }}>F_{\text {tabel }}$ maka Ho ditolak.

Hipotesis yang akan diuji adalah hipotesis statistik:

Ho = Tidak ada pengaruh model pembelajaran concept sentence dalam menulis cerpen.

$\mathrm{Ha}=$ Ada pengaruh model pembelajaran concept sentence dalam menulis cerpen.

Ho $: \mu 1=\mu 2$

$\mathrm{Ha}: \mu 1 \neq \mu 2$

Keterangan :

$\mu 1=$ nilai rata-rata kelas eksperimen

$\mu 2=$ nilai rata-rata kelas kontrol

Alternatif pemilihan uji t:

a. Tentukan nilai $\mathrm{a}=$ tingkat nyata yang homogen $\left(\sigma_{1}=\sigma_{2}\right.$ dan $\sigma$ tidak (signifikan level $=$ probabilitas) untuk diketahui), maka digunakan rumus uji t. melakukan keslahan jenis 1 dan cari Jika data berasal dari populasi yang nilai $\mathrm{Z}_{\mathrm{a}}$ atau $\mathrm{Z}_{\mathrm{a} / 2}$ dari tabel normal.

b. Hitung Zo sebagai kriteria tidak homogen tetapi berdistribusi pengujian, rumus untuk $n \geq 30$. Jika $n>$ 30 maka $\mathrm{Zo}, \mathrm{Z}_{\mathrm{a}}$ atau $\mathrm{Z}_{\mathrm{a} / 2}$ diganti dengan normal $\left(\sigma_{1} \neq \sigma_{2}\right.$ dan $\sigma$ tidak diketahui) hingga sekarang belum ada ststistik yang tepat yang dapat digunakan. to, ta, atau ta/2. Dengan rumus to adalah Pendekatan yang cukup memuaskan derajat kebebasan $n-1$. adalah dengan menggunakan statistik $\mathrm{t}$ c. Jika data berasal dari populasi sebagai berikut:

$$
\begin{gathered}
t=\frac{X_{1}-X_{2}}{\overline{\frac{S_{\underline{2}}^{1}}{n_{1}}+\frac{S_{2}^{2}}{n_{2}}}} \\
(S D)^{2}=\frac{(N-1)\left(S D^{1}\right)^{2}+\left(N^{2}-1\right)\left(S D^{2}\right)^{2}}{n-1}
\end{gathered}
$$


Keterangan $: \mathrm{SD}^{2}=$ Standart Deviasi

$\mathrm{SD}_{1}=$ Standart Deviasi Kelas Eksperimen

$\mathrm{SD}_{2}=$ Standart Deviasi Kelas Kontrol

$\mathrm{N}=$ Jumlah Sampel 
Selanjutnya untuk menguji hipotesis apakah kebenarannya diterima atau tidak digunakan uji $\mathrm{t}$ student dengan rumus sebagai berikut :

$$
t=\frac{M^{1}-M_{2}}{S D M^{1}-M_{2}}
$$

Keterangan :

$$
\begin{array}{ll}
\mathrm{T} & =\text { Harga } t \text { hitung } \\
\mathrm{M}_{1} & =\text { Nilai Rata-rata Kelas Eksperimen } \\
\mathrm{M}_{2} & =\text { Nilai Rata-rata Kelas Kontrol } \\
\mathrm{SD} 2 & =\text { Varians Masing-masing Nilai Tes }
\end{array}
$$

Selanjutnya mengkonsultasikan harga t-tabel pada taraf signifikan 5\% dengan kriteria sebagai berikut :

Jika $t_{\text {hitung }}<t_{\text {tabel }}$ maka signifikasi ( hipotesis diterima) Jika $t_{\text {hitung }}>t_{\text {tabel }}$ maka tidak signifikasi ( hipotesis ditolak)

\section{PEMBAHASAN}

Setelah dilakukan penelitian dengan judul Pengaruh Model Pembelajaran Concept Sentence terhadap Keterampilan Menulis Cerpen pada Siswa Kelas XI MIA SMA Muhammadiyah 18 Sunggal Tahun Pelajaran 2019/2020, maka diperoleh data hasil penelitian. Selanjutnya, data tersebut dianalisis dengan menggunakan perhitungan nilai data rata-rata dan simpangan baku serta menguji kedua variabel, yaitu variabel $\mathrm{X}$ dan variabel $\mathrm{Y}$. Diketahui bahwa perhitungan variabel $\mathrm{X}$ didapat nilai rata-rata 82,82 dan standart deviasi 9,10, dan variabel $\mathrm{Y}$ didapat nilai rata-rata 70,96 dan standart deviasi 8,42 .

Dari perhitungan hipotesis harga $\mathrm{t}=0,07$ signifikasi koefisien hipotesis tersebut dikonsultasikan dengan tabel nilai thitung. Harga $t_{\text {tabel }}$ dengan $\mathrm{N}=59$ pada taraf signifikan $5 \%=0,245$. Dengan ini ternyata $0,07<0,245$, maka hal ini membuktikan bahwa hipotesis terdapat pengaruh.

\section{KESIMPULAN}

Berdasarkan hasil penelitian dan pengolahan data, maka diperoleh kesimpulan : 
1. Nilai rata-rata tes uraian menulis cerpen dengan menggunakan model pembelajaran concept sentence sebesar 82,82 dengan nilai standart deviasi 9,10, untuk nilai rata-rata tes uraian menulis cerpen tanpa menggunakan model pembelajaran concept sentence sebesar 70,96 dengan nilai standart deviasi 8,42 .

2. Dari hasil uji hipotesis didapat $t_{\text {hitung }}$ $<t_{\text {tabel }}$ sehingga Ha diterima dan Ho ditolak. Maka terdapat pengaruh model pembelajaran concept sentence terhadap keterampilan menulis cerpen pada siswa kelas XI Mia SMA Muhammadiyah 18 Sunggal Tahun Pelajaran 2019/020.

\section{DAFTAR PUSTAKA}

Aminudin. 2007. Pandai Memahami \& Menulis Cerita Pendek. Bandung: PT Pribumi Mekar.

Arikunto, Suharsimi. 2001. Prosedur Penelitian Sebagai

Dalman, H. 2014. Keterampilan Menulis. Jakarta: Rajawali Pers.

Furchan, H. Arif. Pengantar Penelitian Dalam Pendidika. Yogyakarta: Pustaka Pelajar.

Kosasih. Ketatabahasaan dan Kesusastraan, Bandung: Yrama Widya.

Purba, Antilan. 2001. Sastra Indonesia Kontemporer. Medan: USU PRESS.

\section{Rusman. 2014. Model-Model}

Pembelajaran. Jakarta: PT Raja Grafindo Persada.

Tarigan, Henry Guntur. 1994. Menulis Sebagai Suatu Keterampilan Berbahasa.Bandung: Angkasa. 